\title{
Improved Learning Outcomes of Natural Science Lessons Through Google Meet Assisted Project Based Learning (PjBL) Learning Models
}

\section{Wahyu Agung Nugroho}

SD Negeri 2 Cilongok

agias.wagu@gmail.com

\section{Article History}

accepted 01/11/2020

\begin{abstract}
The purpose of this research was to improve student learning outcomes in science grade $V$ elementary schools with a Google meet assisted Project Based Learning (PjBL) learning model. The research conducted was a Classroom Action Research (PTK) with three cycles, with each cycle consisting of two meetings. The stages of each cycle are planning, implementing, observing and reflecting. Each meeting is carried out a pre test and post test to determine the progress of students. In the first cycle the students who completed after carrying out the post test were $74 \%$. In the second cycle students who completed after carrying out the post test were $87 \%$. In the third cycle students who completed after carrying out the post test were $90 \%$. These results indicate that the Project Based Learning (PJBL) learning model can improve student learning outcomes, especially grade $V$ science at SDN 2 Cilongok.
\end{abstract}

Keywords: Learning outcomes, Project Based Learning, Science

\section{Abstrak}

Tujuan dari penelitian ini adalah untuk meningkatkan hasil belajar peserta didik pada mupel IPA di sekolah dasar kelas $\mathrm{V}$ dengan model pembelajaran Project Based Learning (PjBL) berbantuan google meet. Penelitian yang dilakukan adalah Penelitian Tindakan Kelas (PTK) sebanyak tiga siklus, dengan setiap siklusnya terdiri dari dua pertemuan. Tahapan setiap siklusnya adalah perencanaan, pelaksanaan, observasi dan refleksi. Setiap pertemuan dilakukan pre test dan post test untuk mengetahui perkembangan peserta didik. Pada siklus I peserta didik yang tuntas setelah melaksanakan post test sebesar $74 \%$. Pada siklus II peserta didik yang tuntas setelah melaksanakan post test sebesar $87 \%$. Pada siklus III peserta didik yang tuntas setelah melaksanakan post test sebesar $90 \%$. Hasil ini menunjukan bahwa model pembelajaran Project Based Learning (PjBL) dapat meningkatkan hasil belajar peserta didik khususnya mupel IPA Kelas V di SDN 2 Cilongok.

Kata kunci: Hasil belajar, Project Based Learning, IPA

Social, Humanities, and Education Studies (SHEs): Conference Series https://jurnal.uns.ac.id/shes 


\section{PENDAHULUAN}

Ketika virus corona datang semua tatanan berubah begitupun terhadap dunia pendidikan. Pembelajaran tatap muka di sekolah dilarang diganti dengan pembelajaran dari rumah sesuai dengan Surat Edaran Nomor 4 Tahun 2020 Tentang Pelaksanaan Kebijakan Pada Masa Pandemi Belajar dari Rumah melalui pembelajaran daring/jarak jauh dilaksanakan untuk memberikan pengalaman belajar yang bermakna bagi peserta didik, tanpa terbebani tuntutan menuntaskan seluruh capaian kurikulum untuk kenaikan kelas maupun kelulusan. Masalah yang baru pun muncul, selain bagaimana melaksanakan pembelajaran jarak jauh tetapi juga bagimana cara guru tetap melakukan proses pembelajaran yang baik selama pandemi. Proses pembelajaran yang baik harus disesuaikan dengan karakteristik peserta didik agar peserta didik dapat menangkap materi yang diajarkan dengan baik. Pembelajaran yang dilakukan oleh guru juga harus kreatif dan tidak boleh monoton sehingga peserta didik tidak bosan. Penyampaian materi juga harus bervariasi agar peserta didik terdorong semangatnya sehingga aktif dan terus belajar. Guru tidak hanya berfokus pada penyampaian materinya tetapi juga harus memperhatikan perkembangan peserta didik yang terjadi di dalam proses pembelajaran.

Menurut Brunner dalam Sugandi (2007:36) ada empat hal pokok penting yang perlu diperhatikan yaitu peranan pengalaman struktur pengetahuan, kesiapan mempelajari sesuatu, intuisi dan cara membangkitkan motivasi belajar. Guru dituntut untuk bisa membawa peserta didik ke dalam dunia yang menyenangkan di dalam pembelajaran. Peserta didik yang merasa nyaman dan senang, maka akan berani untuk aktif dan akan mempunyai motivasi lebih untuk terus belajar. Peserta didik yang mempunyai motviasi lebih untuk belajar biasanya akan mendapatkan hasil belajar yang baik. Guru sebagai pemegang proses pembelajaran harus bisa menyajikan hal terbaik. Model pembelajaran yang digunakan haruslah sesuai dengan materi yang sedang diajarkan, karena tidak semua model pembelajaran dapat digunakan untuk semua materi. Pemilihan model pembelajaran akan mendukung hasil pembelajaran yang akan dicapai. Semua muatan pelajaran membutuhkan penerapan model pembelajaran.

Salah satu muatan pelajaran yang menuntut penggunaan model pembelajaran yang sesuai adalah muatan pelajaran IImu pengetahuan alam (IPA) merupakan ilmu yang mempelajari tentang gejala alam berupa fakta, konsep dan hukum yang telah teruji kebenarannya melalui suatu rangkaian penelitian. Pembelajaran IPA diharapkan dapat membantu siswa untuk memahami fenomena-fenomena alam (Fitriyati, dkk, 2017). Pengujian teori yang ada di dalam IPA dapat dilakukan melalui proses pembelajaran. Proses pembelajaran yang berlangsung harus bisa membuat peserta didik mengerti mengenai teori IPA. Pembelajaran IPA yang memberikan kesempatan siswa untuk mengkonstruksi konsep sendiri, akan memberikan pengalaman langsung untuk menjelajahi dan memahami alam sekitar secara ilmiah. Pembelajaran IPA dengan memberikan pengalaman langsung dapat menumbuhkan cognitive thingking skill (keterampilan berpikir kognitif), psychomotor skills (keterampilan psikomotorik) dan social skills (keterampilan sosial) (Prabowo, 2015).

Penggunaan model pembelajaran harus sesuai dengan materi yang disampaikan, jika tidak sesuai maka tujuan pembelajaran yang diiginkan tidak akan tercapai. Hasil belajar IPA juga akan rendah karena peserta didik tidak memahami materi pelajaran yang disampaikan. Kasus rendahnya pemahaman peserta didik mengenai materi IPA masih banyak terjadi di SD di sekitar kita, seperti halnya di SD Negeri 2 Cilongok. Hasil belajar IPA pada peserta didik kelas $V$ masih rendah, hal ini dapat dilihat dari hasil Penilaian Tengah Semester (PTS) 1 dimana hanya terdapat $54 \%$ peserta didik yang sudah dinyatakan tuntas dengan Kriteria Ketuntasan Minimum (KKM) sebesar 68. Ketuntasan belajar klasikal belum tercapai, yaitu sebesar $75 \%$ peserta didik memperoleh nilai di atas KKM. 
Menurut Sujana (2009: 3) hasil belajar peserta didik pada hakekatnya adalah perubahan tingkah laku. Tingkah laku sebagai hasil belajar dalam pengertian yang luas mencakup bidang kognitif, afektif dan psikomotoris. Selain perubahan tingkah laku, jika di sekolah hasil belajar biasanya dinilai dengan angka. Peserta didik akan mendapat nilai yang akan menggambarkan keberhasilan dalam belajar. Pembelajaran IPA pada penelitian ini menggunakan model pembelajaran Project Based Learning (PjBL) merupakan salah satu model pembelajaran yang berpijak pada teori belajar konstruktivistik. Driscoll dalam Miyarso (2019: 120) menyatakan prinsip-prinsip pembelajaran kontruktivistik adalah melibatkan pebelajar dalam aktivitas nyata, negosiasi sosial dalam proses belajar, kolaboratif dan pengkajian multiperspektif, dukungan menentukan tujuan dan mengatur proses belajar, dan dorongan merefleksikan apa dan bagaimana sesuatu dipelajari. Menurut Surya, dkk (2018) Model pembelajaran Project Based Learning ( $\mathrm{PjBL}$ ) merupakan pembelajaran yang inovatif yang berpusat kepada siswa (Student Centered) dan menempatkan guru sebagai motivator dan fasilitator, dimana dalam hal ini siswa diberi peluang untuk bekerja secara otonom mengkonstruksi belajarnya. Model pembelajaran berbasis proyek (Project Based Learning) siswa merancang sebuah masalah dan mencari penyelesaiannya sendiri, sehingga mampu meningkatkan kreatifitas siswa untuk memunculkan penyelesaiannya sendiri membuat kegiatan pembelajaran lebih bermakna sehingga teringat.

Menurut Nurfitriyanti (2016) project based learning adalah pembelajaran yang memerlukan jangka waktu panjang, menitikberatkan pada aktifitas peserta didik untuk dapat memahami suatu konsep atau prinsip dengan melakukan investigasi secara mendalam tentang suatu masalah dan mencari solusi yang relevan serta diimplementasikan dalam pengerjaan proyek, sehingga peserta didik mengalami proses pembelajaran yang bermakna dengan membangun pengetahuannya sendiri.Penekanan pembelajaran terletak pada aktifitas peserta didik untuk memecahkan masalah dengan menerapkan keterampilan meneliti, menganalisis, membuat, sampai dengan mempresentasikan produk pembelajaran berdasarkan pengalaman nyata. Metode pembelajaran project based learning memperkenankan peserta didik untuk dapat bekerja mandiri maupun dengan cara berkelompok dalam menghasilkan hasil proyeknya yang bersumber dari masalah kehidupan sehari-hari. Langkah dalam model pembelajaran Project Based Learning sangat memerlukan kemampuan berpikir kreatif siswa. Suatu proyek yang ideal adalah merupakan sesuatu yang baru dan asli, namun hal ini tidaklah mutlak bagi siswa. Dapat pula siswa bekerja dalam suatu proyek yang bertolak dari ide orang lain, tetapi kemudian mengadakan modifikasi dari dasar pemikiran (Efrimal, dkk, 2017).

\section{METODE}

Penelitian ini adalah penelitian tindakan kelas (Classroom Action Research) dengan menerapkan model pembelajaran Project Based Learning (PjBL). Menurut Kurt Lewin dalam Kunandar (2011: 42) penelitian tindakan kelas ini terdiri dari empat tahapan dasar yaitu perencanaan (planning), pelaksanaan (acting), pengamatan (observing) dan refleksi (reflecting). Analisis penelitian ini adalah analisis deskriptif kuantitafif kualitatif dimana dalam penelitian ini selain penyajian hasil berupa data maupun angka peneliti juga menentukan bagaimana cara pengolahan hasil penelitian yakni dengan membuat analisisnya dengan menerapkan model penelitian Project Based Learning (PjBL). Penelitian ini dilaksanakan pada peserta didik kelas V SD Negeri 2 Cilongok Tahun Pelajaran 2020/2021 selama tiga siklus secara daring menggunakan aplikasi Google meet dengan dua pertemuan disetiap siklusnya. Siklus I dilaksanakan pada tanggal 22 dan 23 Oktober 2020. Siklus II dilaksanakan pada tanggal 2 dan 3 November 2020. Siklus III dilaksanakan pada tanggal 13 dan 14 November 2020. Teknik pengumpulan data yang dilakukan dengan observasi dan tes, 
baik pre test maupun post test. Observasi meliputi observasi keterlaksanaan model pembelajaran $\mathrm{PjBL}$, sikap peserta didik dan keterampilan. Untuk hasil belajar menggunakan tes melalui Google form.

\section{HASIL DAN PEMBAHASAN}

Pada siklus I pembelajaran dilaksanakan selama dua pertemuan, setiap pertemuan diadakan pre test dan post test. Untuk mengetahui perkembangan peserta didik selama pembelajaran. Siklus I membahas materi tentang rantai makanan, berupa komponen dalam rantai makanan dan permasalahan jika salah satu populasi punah dalam rantai makanan. Pembelajaran dengan model PjBL dilaksanakan dengan 6 langkah PjBL secara berurutan mulai dari menentukan pertanyaan mendasar, merancang proyek, menyusun jadwal, memantau proses proyek, penilaian hasil dan evaluasi pengalaman. Proyek yang dibuat peserta didik adalah menyusun rantai makanan dengan gambar yang tepat. Berikut ini adalah hasil belajar peserta didik pada siklus I yang bisa dilihat pada tabel berikut.

Tabel 1. Hasil Belajar Peserta Didik Siklus I

\begin{tabular}{ccccccccc}
\hline \multirow{2}{*}{ Siklus I } & \multicolumn{3}{c}{ Pre test } & \multicolumn{3}{c}{ Post test } \\
\cline { 2 - 9 } & $\begin{array}{c}\text { Pesdik } \\
\text { tuntas }\end{array}$ & \multicolumn{2}{c}{$\begin{array}{c}\text { Pesdik belum } \\
\text { tuntas }\end{array}$} & \multicolumn{2}{c}{$\begin{array}{c}\text { Pesdik } \\
\text { tuntas }\end{array}$} & \multicolumn{2}{c}{$\begin{array}{c}\text { Pesdik belum } \\
\text { tuntas }\end{array}$} \\
\cline { 2 - 9 } & Jml & $\%$ & Jml & $\%$ & Jml & $\%$ & Jml & $\%$ \\
\hline Pertemuan 1 & 9 & 27 & 22 & 71 & 20 & 65 & 11 & 35 \\
\hline Pertemuan 2 & 11 & 35 & 20 & 65 & 23 & 74 & 8 & 26 \\
\hline
\end{tabular}

Berdasarkan tabel di atas maka terjadi peningkatan antara pre test dan post test pada pertemuan 1. Setiap individu peserta didik sudah mengalami peningkatan hasil belajarnya. Peserta didik mengalami peningkatan hasil belajar pada pertemuan 1 . Ketuntasan klasikal juga mengalami peningkatan, pada pre test hanya terdapat 9 anak yang sudah tuntas, tetapi pada post test bertambah menjadi 20 anak yang sudah tuntas dengan Kriteria Ketuntasan Minimal (KKM) sebesar 70. Demikian juga pada pertemuan 2 jumlah peserta didik yang sudah tuntas KKM mengalami peningkatan. Pada pre test ada 11 anak yang baru tuntas, sudah meningkat menjadi 23 peserta didik yang tuntas setelah melaksanakan post test. Perbandingan antara hasil post test pada pertemuan 1 dan pertemuan 2 juga terdapat perbedaan. Pada pertemuan 1 peserta didik yang sudah tuntas hanya ada 20 anak, sedangkan pada pertemuan 2 sudah meningkat menjadi 23 anak. Persentase ketuntasan klasikalnya meningkat, jika pertemuan 1 hanya $67 \%$ maka pada pertemuan 2 menjadi $74 \%$.

Berdasarkan refleksi pada siklus I maka diputuskan untuk melanjutkan ke siklus II dikarenakan belum mencapai ketuntasan klasikal yang diharapkan. Siklus II membahas materi tentang jaring-jaring makanan dan terganggunya jaru=ing-jaring makanan pada suatu ekosistem. Pembelajaran dengan model PjBL dilaksanakan dengan 6 langkah PjBL secara berurutan seperti siklus I Proyek yang dibuat peserta didik adalah menyusun jaring-jaring dengan gambar yang tepat. Berikut ini adalah hasil belajar peserta didik pada siklus II yang bisa dilihat pada tabel berikut.

Tabel 2. Hasil Belajar Peserta Didik Siklus II

\begin{tabular}{ccccccccc}
\hline \multirow{2}{*}{ Siklus II } & \multicolumn{3}{c}{ Pre test } & \multicolumn{3}{c}{ Post test } \\
\cline { 2 - 9 } & $\begin{array}{c}\text { Pesdik } \\
\text { tuntas }\end{array}$ & \multicolumn{2}{c}{$\begin{array}{c}\text { Pesdik belum } \\
\text { tuntas }\end{array}$} & \multicolumn{2}{c}{$\begin{array}{c}\text { Pesdik } \\
\text { tuntas }\end{array}$} & $\begin{array}{c}\text { Pesdik belum } \\
\text { tuntas }\end{array}$ \\
\cline { 2 - 10 } Jml & $\%$ & Jml & $\%$ & Jml & $\%$ & Jml & $\%$ \\
\hline Pertemuan 1 & 19 & 61 & 12 & 39 & 25 & 81 & 6 & 19 \\
\hline Pertemuan 2 & 25 & 81 & 6 & 19 & 27 & 87 & 4 & 13 \\
\hline
\end{tabular}


Berdasarkan tabel di atas maka terjadi peningkatan antara pre test dan post test pada pertemuan 1. Setiap individu peserta didik sudah mengalami peningkatan hasil belajarnya. Ketuntasan klasikal juga mengalami peningkatan, pada pre test hanya terdapat 19 anak yang sudah tuntas, tetapi pada post test bertambah menjadi 25 anak yang sudah tuntas dengan Kriteria Ketuntasan Minimal (KKM) sebesar 70. Demikian juga pada pertemuan 2 jumlah peserta didik yang sudah tuntas KKM mengalami peningkatan. Pada pre test ada 21 anak yang baru tuntas, sudah meningkat menjadi 27 peserta didik yang tuntas setelah melaksanakan post test. Perbandingan antara hasil post test pada pertemuan 1 dan pertemuan 2 juga terdapat perbedaan. Pada pertemuan 1 peserta didik yang sudah tuntas hanya ada 25anak, sedangkan pada pertemuan 2 sudah meningkat menjadi 27 anak. Persentase ketuntasan klasikalnya meningkat, jika pertemuan 1 hanya $81 \%$ maka pada pertemuan 2 menjadi $87 \%$.

Setelah melakukan refleksi pada siklus II, maka diputuskan untuk melanjutkan pada siklus III. Hal ini dilakukan agar mengetahui sejauh mana penerapan pembelajaran PjBL tidak hanya meningkatkan tetapi juga mempertahankan hasil belajar peserta didik. Pada siklus III materi yang diajarkan adalah simbiosis, peserta didik mengerjakan proyek sebuah pamflet berisi informasi tentang simbiosis. Hasil belajar peserta didik dapat dilihat pada tabel berikut.

Tabel . Hasil Belajar Peserta Didik Siklus III

\begin{tabular}{ccccccccc}
\hline \multirow{2}{*}{ Siklus II } & \multicolumn{3}{c}{ Pre test } & \multicolumn{3}{c}{ Post test } \\
\cline { 2 - 9 } & $\begin{array}{c}\text { Pesdik } \\
\text { tuntas }\end{array}$ & \multicolumn{2}{c}{$\begin{array}{c}\text { Pesdik belum } \\
\text { tuntas }\end{array}$} & \multicolumn{2}{c}{$\begin{array}{c}\text { Pesdik } \\
\text { tuntas }\end{array}$} & $\begin{array}{c}\text { Pesdik belum } \\
\text { tuntas }\end{array}$ \\
\cline { 2 - 9 } & Jml & $\%$ & Jml & $\%$ & Jml & $\%$ & Jml & $\%$ \\
\hline Pertemuan 1 & 20 & 65 & 11 & 35 & 27 & 87 & 4 & 13 \\
\hline Pertemuan 2 & 22 & 71 & 9 & 29 & 28 & 90 & 3 & 10 \\
\hline
\end{tabular}

Ketuntasan klasikal mengalami peningkatan, pada pre test hanya terdapat 20 anak yang sudah tuntas, tetapi pada post test bertambah menjadi 27 anak yang sudah tuntas dengan Kriteria Ketuntasan Minimal (KKM) sebesar 70. Demikian juga pada pertemuan 2 jumlah peserta didik yang sudah tuntas KKM mengalami peningkatan. Pada pre test ada 22 anak yang baru tuntas, sudah meningkat menjadi 28 peserta didik yang tuntas setelah melaksanakan post test. Perbandingan antara hasil post test pada pertemuan 1 dan pertemuan 2 juga terdapat perbedaan. Pada pertemuan 1 peserta didik yang sudah tuntas hanya ada 27 anak, sedangkan pada pertemuan 2 sudah meningkat menjadi 28 anak. Persentase ketuntasan klasikalnya meningkat, jika pertemuan 1 hanya $87 \%$ maka pada pertemuan 2 menjadi $90 \%$.

Dari tiga siklus yang sudah dilaksanakan selama 6 pertemuan dapat dipastikan bahwa model pembelajaran PjBL dapat meningkatkan hasil belajar peserta didik pada mupel IPA Kelas V di SD Negeri 2 Cilongok. Hal ini sesuai dengan konsep atau teori yang diungkap oleh Nanang Hanafiah dan Cucu Suhana (2009:30) bahwa langkah penerapan Model pembelajaran ini merupakan model pembelajaran inovatif yang melibatkan kerja proyek dimana peserta didik bekerja secara mandiri dalam mengkonstruksi pembelajarannya dan mengkulminasikannya dalam produk nyata. Memang benar adanya dengan model PjBL peserta didik akan membangun sendiri pengetahuannya dengan mengerjakan proyek yang diberikan. Peserta didik dapat memahami komponen rantai makanan dan urutan ringkat konsumen dalam rantai makanan dengan tepat. Pada siklus II peserta didik juga dapat memahami jaring-jaring makanan dengan membuat sendiri jaring-jaring makanan dalam proyek sehingga pengetahuan yang dihasilkan dapat tertanam dengan permanen. Hasil penelitian ini juga sesuai dengan penelitian sebelumnya yang dilakukan oleh Surya, dkk (2018) yang membuktikan bahwa model pembelajaran Project Based Learning (PjBL) dapat meningkatkan hasil belajar dan kreativitas peserta didik. 


\section{SIMPULAN}

Penerapan model pembelajaran Project Based Learning (PjBL) dapat meningkatkan hasil belajar peserta didik Kelas $\mathrm{V}$ pada mupel IPA materi rantai makanan. Peningkatan yang terjadi karena adanya kesan pembelajaran yang mendalam dari peserta didik tehadap materi yang diajarkan melalui setiap proyek yang dibuat. Peserta didik akan selalu teringat akan materi yang diajarkan dikarenakan mereka menemukan dan membangun sendiri pengetahuan mereka pada saat membuat proyek yang sudah disepakati. Berdasarkan penelitian yang telah dilaksanakan salah satu model pembelajaran yang harus dikuasai guru adalah PjBL karena model ini sangat cocok digunakan dalam keadaan pandemi seperti ini, apalagi dalam kondisi belajar dari rumah. Peserta didik akan membangun pengetahuannya sendiri dengan proyek yang sudah disepakati. Guru bisa memantau proses selama proyek dilaksanakan dengan bekerja sama denagn orang tua.

\section{DAFTAR PUSTAKA}

Erfrimal, F, dkk. (2017). Penerapan Model Project Based Learning (PjBL) untuk Meningkatkan Kecermatan dan Kreasi Seni Rupa. DIADIK : Jurnal Ilmiah Teknologi Pendidikan, 7(2). 48-61.

Fitriyati, I, dkk. (2017). Pengembangan Perangkat Pembelajaran IPA untuk Meningkatkan Kemampuan Berpikir Tinggi dan Penalaran IImiah Siswa Sekolah Menengah Pertama. Jurnal Pembelajaran Sains, 4(1). 27-34.

Hanafiah, dan Cucu Suhana. 2009. Konsep Strategi Pembelajaran. Bandung: PT Refika aditama

Kunandar. 2011. Langkah Mudah Penelitian Tindakan Kelas Sebagai Pengembang Profesi Guru. Jakarta: PT Raja Grafindo Persada.

Miyarso, E. 2019. Perancangan Pembelajaran Inovatif. Jakarta: Kemdikbud.

Nurfitriyanti, M. (2016). Model Pembelajaran Project Based Learning Terhadap Kemampuan Pemecahan Masalah Matematika. Jurnal Formatif, 6(2). 140-160.

Prabowo, S. A. (2015). The effectiveness of scientific based learning towards science process skill mastery of PGSD students. Jurnal Pendidikan IPA Indonesia, 4(1), 15-19.

Sugandi, A. 2007. Teori Pembelajaran. Semarang: UNNES Press.

Surya. A.P, dkk (2018). Penerapan Model Pembelajaran Project Based Learning (PjBL) untuk Meningkatkan Hasil Belajar dan Kreativitas Siswa Kelas III SD Negeri Sidojero Lor 01 Salatiga. Jurnal Pesona Dasar, 6(1), 51-54.

Sudjana, N. 2009. Penilaian Hasil Proses Belajar Mengajar (Cetakan Ketigabelas). Bandung: PT Remaja Rosdakarya. 